\title{
THE ANALYSIS OF THE CONTRACTS AWARDED ON THE BASIS OF A SINGLE TENDER IN THE PUBLIC PROCUREMENT IN ROMANIA
}

\section{lonel Preda}

Doctoral School of Management, Faculty of Management, Bucharest University of Economic Studies, Bucharest, Romania

predaionel4@gmail.com

\begin{abstract}
The analysis of the contracts awarded on the basis of a single tender in public procurement is necessary to be performed for studying the degree of openness of a market and for identifying a number of deficiencies such as reduced competition, high level of bureaucracy, reduced stimulation of the small and medium entreprises participation at the procurement procedures or non-splitting into lots the object of the procurement. The article describes the existing specialised literature, the advantages and disadvantages of receiving only one tender situation in Romania and European Union during the period 2015 - 2017, in correlation with the statistics regarding the weight of conracts awarded to small and medium entreprises and the weight of procurement procedures divided into lots. Also, the article longer poses a number of issues concerning the approach of contracts contracts based on only one offer as an indication of fraud or corruption or the conclusion of anticompetitive agreements.
\end{abstract}

Keywords: public procurement, procurement procedure, contract, only one tender.

JEL classification: C46, H57, H83.

\section{Introduction}

UNDP - United Nations Development Programme (2007), apud Thai (2009: 4), considers that public procurement is a comprehensive process of purchasing products, services and civil works that includes all the functions from identifying the need, selecting the supplier, requesting the offers, preparating, awarding and administrating the contract until the end of the asset's useful life or the service delivery.

In Romania, article 3 from Law 98/2016 regarding public procurement defines public procurement as the acquisition of works, goods or services through a contract by a contracting authority or several contracting authorities from designated economic operators regardless if this works, goods or services are destined for the achievement of a public interest or not.

Currently, in the world it can be observed an increase of the public opinion pressure on governments in order to spend public funds as efficient as possible. This goal can be achieved through the analysis of procurement procedures in which only one tender was submitted, to identify the measures regarding the increase of the level of competition and reduction of purchasing prices.

The necessity to examine the procurement procedures with only one tender results from the fact that this situation is the most disadvantageous for contracting authority that must accept the offer (which often doesn't represent the lowest price that public authority can obtain from the free market) or disadvantageous contractual clauses. 


\section{Literature review}

Thai et al. (2009) consider that competition cut custs and that important differences exist between types of procurement (civil or military). The recomandation of the authors is that contracting authorities should have at least four tenderers. In the situation with three tenderers, situation is worse and when there is only one tenderer, the situation is catastrophic (Thai et al., 2009).

During times of economic crisis, Gugler, Weichselbaumer and Zulehner (2014) found that negative demand increases the competition, because the firms bid much more aggressively in the remaining procurement procedures.

The determining factors that influence final price are: tenderer's features, type of services / products, procurement procedure's type, sector features and of couse number of tenderers (Brannman, 1987, apud Grega and Nemec, 2015: 3).

Furthermore, Rose-Ackerman (1999), apud Grega and Nemec (2015: 3), consider that if tenderers found that they are competing with other tenderers, submitting offers in the procedure slowed down because bidders compare potential profit with participation costs and if the number of bidders are higher, then the potential profit decreases significantly.

The procurement procedures with only one tender present a number of advantages and disadvantages. The main advantages of the single offer situation are:

- workload reduction necessary for the analysis of submitted offer or meeting technical specifications requested in tender documents;

- reduction of offer assessment period and for the procedure completion;

- risk reduction / elimination for the submission of appeals.

The main disadvantages of the single offer situation are:

- reduction of competition can result in awarding offers with high prices, leading to inefficiency of public funds spending. As regards to necessary competition level for getting a appropriate response from the specialized market, several authors like Brannman (1987), Gupta, (2002), Gineitiene and Serpytis, (2011), Pavel, (2010), Ilke, Rasim and Bedri (2012), all apud Grega and Nemec (2015: 2-4), have carried out studies according to which the price decrease stops with the increase of the number of participants / offers above $6-8$ tenderers. After this point, any aditional received offer doesn't hane any effect over the final price, reaching the maximum competitiveness of the procurement;

- imposition by the only tenderer of disadvantageous contractual clauses for the public authority which can only to accept them or to cancel the procurement procedure;

- knowing that it was the only participant, the tenderer can try to deliver to the contracting authority products or services of inferior quality compared with the requirements from tender documents, in order to maximize the profit;

- in the event that procurement procedure also has stages of negotiation, these rounds can become very difficult to conduct because the tenderer may adopt a position of strength through which to make very few concessions to public authority.

\section{Research objectives and working hypotheses}

Even though public procurement procedures are regulated at European level by a series of public procurement directives, there are significant differences between the results of the procurement procedures carried out in EU Member States.

The research aims to identify some of these differences between Romania and the rest of the EU Member States, regarding contracts awarded on the basis of a single tender, winning the procurement procedures by small and medium-sized companies and dividing the object of the procurement procedures into lots.

Also, the research aims to demonstrate that a procurement procedure for which a single tender has been received can be interpreted as a signal (red flag) regarding the occurrence 
of fraud and corruption situations. The working hypothesis of the research is that dividing the object of the procedures into lots leads to an increase in the number of small and medium-sized companies participating in the procedures (increased competition), a reduction of the number of procedures for which a single tender was received, a reduction of final prices and implicitly in the efficient spending of public funds.

\section{The analysis of the contracts based on only one offer in the public procurement in Romania}

This indicator (contracts based on only one offer) shows the economic competitiveness and bureaucratic level of procurement procedures / processes. If more tenderers respond, then contracting authority has more options and obtains more added value for the funds spent. In the year 2015, in Romania was awarded a number of 73,360 contracts. From these contracts, a number of 7,534 was awarded by contracting authorities on the basis of a single offer. In this situation was not included a number of 20,992 contracts awarded by the call for tenders procedure (ANAP - Romanian National Agency for Public Procurement, 2015).

The total number of awarded contracts, the number of contracts based on only one offer and the distribution by type are presented in Table 1.

Table 1: The total number of awarded contracts and the number of contracts based on only one offer in Romania in 2015

\begin{tabular}{|c|c|c|c|c|c|}
\hline No. & $\begin{array}{c}\text { Contract } \\
\text { type }\end{array}$ & $\begin{array}{c}\text { Number of } \\
\text { awarded contracts }\end{array}$ & Weight & $\begin{array}{c}\text { Number of contracts } \\
\text { based on only one offer }\end{array}$ & $\begin{array}{c}\text { Weight } \\
\text { from total }\end{array}$ \\
\hline 1 & Products & 62,134 & $84.70 \%$ & 5,912 & $8.06 \%$ \\
\hline 2 & Services & 6,168 & $8.41 \%$ & 1,487 & $2.03 \%$ \\
\hline 3 & Works & 5,058 & $6.89 \%$ & 135 & $0.18 \%$ \\
\hline \multicolumn{2}{|c|}{ Total } & 73,360 & $100 \%$ & 7,534 & $10.27 \%$ \\
\hline
\end{tabular}

Source: ANAP - Romanian National Agency for Public Procurement (2015)

In the year 2016, in Romania were awarded 68,010 contracts and 6,712 of them were awarded with only one offer (Table 2). In this situation were not included 18,976 contracts awarded by the call for tenders / simplified procedure. Therefore, if the total number of contracts taken into consideration would be 49,034 , the number of 6,712 contracts based on only one offer would represent a weight of $13.69 \%$ (ANAP, 2016).

Table 2: The total number of awarded contracts and the number of contracts based on only one offer in Romania in 2016

\begin{tabular}{|c|c|c|c|c|c|}
\hline No. & $\begin{array}{c}\text { Contract } \\
\text { type }\end{array}$ & $\begin{array}{c}\text { Number of } \\
\text { awarded contracts }\end{array}$ & Weight & $\begin{array}{c}\text { Number of contracts } \\
\text { based on only one offer }\end{array}$ & $\begin{array}{c}\text { Weight } \\
\text { from total }\end{array}$ \\
\hline 1 & Products & 58,820 & $86.49 \%$ & 5,340 & $7.85 \%$ \\
\hline 2 & Services & 5,815 & $8.55 \%$ & 1,259 & $1.85 \%$ \\
\hline 3 & Works & 3,375 & $4.96 \%$ & 113 & $0.17 \%$ \\
\hline \multicolumn{2}{r|}{ Total } & 68,010 & $100 \%$ & 6,712 & $9.86 \%$ \\
\hline
\end{tabular}

Source: ANAP (2016)

In the year 2017, in Romania were awarded 74,727 contracts and 12,716 of them were awarded with only one tender (Table 3). 
In this situation were not included 26,947 contracts awarded by the call for tenders / simplified procedure. Therefore, if the total number of contracts taken into consideration would be 47,780 , the number of 12,716 contracts based on only one offer would represent a weight of $26.61 \%$ (ANAP, 2017).

Table 3: The total number of awarded contracts and the number of contracts based on only one offer in Romania in 2017

\begin{tabular}{|c|c|c|c|c|c|}
\hline No. & $\begin{array}{c}\text { Contract } \\
\text { type }\end{array}$ & $\begin{array}{c}\text { Number of } \\
\text { awarded contracts }\end{array}$ & Weight & $\begin{array}{c}\text { Number of contracts } \\
\text { based on only one offer }\end{array}$ & $\begin{array}{c}\text { Weight } \\
\text { from total }\end{array}$ \\
\hline 1 & Products & 60,324 & $80.73 \%$ & 10,241 & $13.70 \%$ \\
\hline 2 & Services & 9,643 & $12.90 \%$ & 2,309 & $3.09 \%$ \\
\hline 3 & Works & 4,760 & $6.37 \%$ & 166 & $0.22 \%$ \\
\hline & Total & 74,727 & $100 \%$ & 12,716 & $17.02 \%$ \\
\hline
\end{tabular}

Source: ANAP (2017)

The graphical representation of total number of awarded contracts and number of contracts based on only one tender in Romania between 2015 and 2017 is presented in Figure 1.

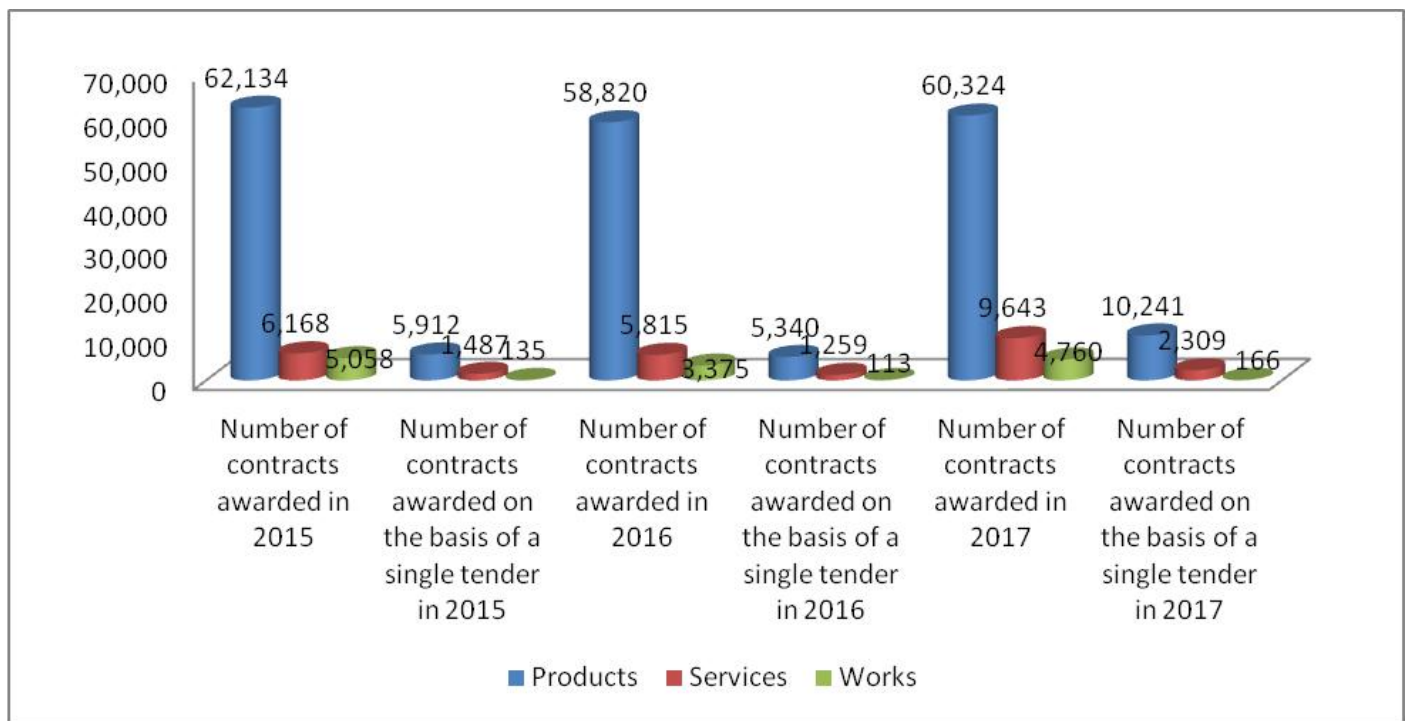

Figure 1: Graphical representation of total number of awarded contracts and number of contracts based on only one tender in Romania between 2015 and 2017

Source: Based on the data in Tables 1, 2 and 3

From the analysis of evolution of the number of contracts based on only one offer during the period $2015-2017$, it can be observed that the number and weight of these contracts has almost doubled in the year 2017 (number 12,716, weight 17.02\%) by comparison with the years 2015 (number 7,534, weight 10.27\%) and 2016 (number 6,712, weight 9.86\%).

In comparison with other European countries, during the period 2015 - 2017, Romania presented one of the highest weightings of the contracts based on only one offer. The weightings of the contracts with only one tender as a result of public procurement procedures carried out in the countries of the European Union are presented in Table 4. The situations alt European level described in the following contain the dates of all the 
procurement procedures conducted in the period in question, including dates of the procurement procedures carried out with European non reimbursable funds.

Table 4: The weight of the contracts based on only one offer during the period $2015-2017$ in European countries (in \%)

\begin{tabular}{|l|c|c|c|}
\hline Country/Year & $\mathbf{2 0 1 5}$ & $\mathbf{2 0 1 6}$ & $\mathbf{2 0 1 7}$ \\
\hline Belgium & 14 & 14 & 19 \\
\hline Bulgaria & 27 & 27 & 32 \\
\hline Czech Republic & 33 & 41 & 47 \\
\hline Denmark & 10 & 12 & 14 \\
\hline Germany & 13 & 17 & 19 \\
\hline Estonia & 22 & 17 & 20 \\
\hline Ireland & 15 & 12 & 11 \\
\hline Greece & 24 & 16 & 34 \\
\hline Spain & 21 & 23 & 23 \\
\hline France & 14 & 15 & 15 \\
\hline Croatia & 44 & 41 & 44 \\
\hline Italy & 29 & 31 & 30 \\
\hline Cyprus & 40 & 38 & 42 \\
\hline Latvia & 32 & 31 & 27 \\
\hline Lithuania & 28 & 17 & 21 \\
\hline Luxemburg & 8 & 10 & 14 \\
\hline Hungary & 36 & 36 & 35 \\
\hline Malta & 12 & 11 & 15 \\
\hline Netherlands & 12 & 12 & 16 \\
\hline Austria & 10 & 14 & 17 \\
\hline Poland & 43 & 46 & 49 \\
\hline Portugal & 25 & 20 & 22 \\
\hline Romania & 36 & 38 & 43 \\
\hline Slovenia & 39 & 37 & - \\
\hline Slovakia & 32 & 31 & 19 \\
\hline Finland & 12 & 13 & 11 \\
\hline Sweden & 12 & 13 & 11 \\
\hline United Kingdom & 11 & 27 & 32 \\
\hline Iceland & 11 & 5 & 10 \\
\hline Liechtenstein & - & 14 & 16 \\
\hline Norway & 12 & 11 & 10 \\
\hline
\end{tabular}

Source: European Commission (2018)

From the situation over a three-year period (2015 - 2017), high levels of the weight of contracts based on only one offer, exceeding $35 \%$, have presented countries such as Romania (RO), Poland (PL), Hungary (HU), Cyprus (CY), Croatia (HR) and Czech Republic $(\mathrm{CZ})$, which are countries with insufficient developed economies or in transition, in circumstances where countries with solid market economies such as Germany (DE), France $(\mathrm{FR})$, Finland $(\mathrm{FI})$ and Sweden (SE) had weightings of the contracts based on only one offer lower than $15 \%$. 
One of the methods by which the competition can be increased and the weight of the contracts based on only one offer can be decreased is the division of the contract's object in lots for encouraging small and medium enterprises participation. That is why, in the following will be analysed at the European level the weight of the contracts awarded to small and medium enterprises and the weight of the procurement procedures divided into lots.

Taking into account that the large majority of the economic operators in the European Union are small and medium enterprises, a high weight of the contracts awarded to small and medium enterprises indicate favouring firms that produce the greatest added value. A small weight indicates bureaucracy, low competition, higher prices and procedures with conditions that firms cannot fulfil.

The weight of contracts awarded to small and medium enterprises in the year 2017 in the European Union countries is presented in Table 5.

Table 5: The weight of contracts awarded to small and medium enterprises in 2017 in the European countries (in \%)

\begin{tabular}{|l|l|l|l|}
\hline \multicolumn{1}{|c|}{ Country } & \% & \multicolumn{1}{c|}{ Country } & \% \\
\hline Belgium & 20 & Hungary & 67 \\
\hline Bulgaria & 53 & Malta & 88 \\
\hline Czech Republic & 63 & Netherlands & 71 \\
\hline Denmark & 54 & Austria & 42 \\
\hline Germany & 44 & Poland & 56 \\
\hline Estonia & 68 & Portugal & 32 \\
\hline Ireland & 63 & Romania & 17 \\
\hline Greece & 37 & Slovenia & 77 \\
\hline Spain & 28 & Slovakia & 62 \\
\hline France & 44 & Finland & 58 \\
\hline Croatia & 47 & Sweden & 61 \\
\hline Italy & 33 & United Kingdom & 49 \\
\hline Cyprus & 76 & Iceland & 66 \\
\hline Latvia & 68 & Liechtenstein & 67 \\
\hline Lithuania & 28 & Norway & 36 \\
\hline Luxemburg & 64 & & \\
\hline
\end{tabular}

Source: European Commission (2018)

Unfortunately, in the year 2017, at the European level, Romania had the lowest weight of the contracts awarded to small and medium enterprises (17\%). From the year 2016, by Romanian Law 98/2016 regarding public procurement, The National Agency for Public Procurement (ANAP) imposed to the contracting authorities to divide into lots the object of the procurement procedure. The contracting authorities have to justify in the procedure documents the reason for not dividing contract object's into lots. The ANAP inspectors can reject the contracting authoritie's justifications and can compel the public authority to divide the procedure's object into lots.

The highest weightings have presented Slovenia (SI), Malta (MT) and Cyprus (CY) with values between $76 \%$ and $88 \%$. These countries have obtained high weightings because of the reduced sized of the national economies that favours the creation and development of small and medium enterprises.

As regards the weight of the procurement procedures divided into lots, it should be mentioned that dividing into lots favours small and medium enterprises participation. High values of this indicator reveal that at the procurement procedures are allowed to participate 
especially the large firms and contracting authorities do not benefit of the opportunities which small and medium enterprises can offer.

The weight of procurement procedures divided into lots during the period $2015-2017$ in the European Union countries is presented in Table 6.

Table 6: The weight of procurement procedures divided into lots during the period 2015 2017 in the European countries (in \%)

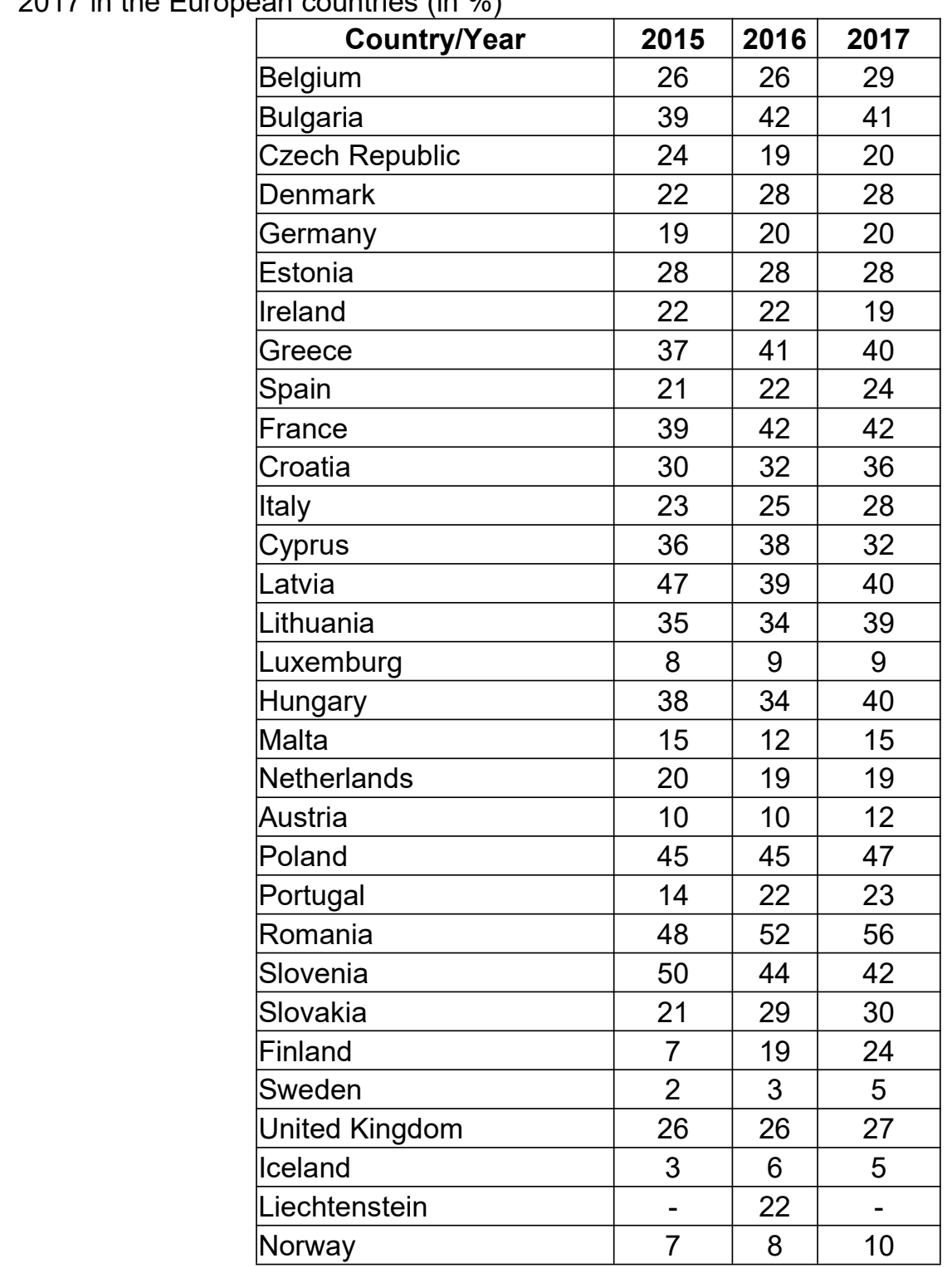

Source: European Commission (2018)

Surprisingly, Romania had the highest weight of procedures divided into lots in the European Union during the period 2015 - 2017 (between 48\% and 56\%).

However appearances can be deceiving, because from the analysis of this indicator an previous one for the year 2017, result that in the case of Romania, even though a large number of procurement procedures have been divided into lots to facilitate participation of 
small and medium entreprises (the highest weight in European Union - 56\%, in the year 2017), these firms have won procedures in a proportion of only $17 \%$ (the lowest weight in EU).

The comparative analysis of these two indicators for the year 2017 reveals that the measures taken by ANAP in 2016 regarding the division into lots of procurement's object and justifying non-splitting in procedure's documents, were not effective. Furthermore, measures for increasing the weight of contracts awarded to small and medium entreprises are necesary to be implemented.

\section{Contracts awarded on the basis of a single tender - indication of fraud situations}

The submission of a single offer in procurement procedures may represent a clue regarding to appearance of fraud or corruption situations. In a procurement procedure, a public authority can introduce several conditions in order to restrict competition and favour a particular economic operator, either in the qualification criteria or in technical specifications.

The specialized literature an mass-media abounding in procurement procedures "with dedication", in which certain technical specifications artificially restrict competition, situations that lead to appeals and to procurement procedures blocking.

A "classic" example of technical specifications "with dedication" for only one economic operator is the procurement procedure regarding taxi services from the "Henri Coandă" Otopeni Airport. Technical specifications of procurement procedure contained the following conditions:

- the economic operator had to have a car park of at least 60 cars produced in the previos year;

- the trunk volume had to be more than 600 litres (Dacia Logan model - the most widespread model in Romania - with a trunk volume of 510 litres, did not meet this condition);

- the colour of the taxi had to be metallic grey (not yellow), although any potential client easily identifies taxis after their yellow colour. Only one firm in Romania was fulfilling all three conditions.

Also, a high number of procedures with only one offer (or a reduced number of offers) can be an indication regarding anticompetitive agreements between economic operators, through which only one firm to submit a tender. These anticompetitive agreements, reduce competition, vulnerabilise public authority in front of the only one tenderer, lead to higher prices and increase the inefficiency of public funds spending.

For example, in Romania, according to Popescu and Preda (2019), a cause of the low numbers of offers received at the procurement procedures having as object the supply of motor vehicles can be the existence of some anticompetitive agreements among the representatives of the same car manufacturer. The authors have analysed 132 procurement procedures during the period 17.02.2015 - 22.12.2018 for supplying motor vehicles and have found that the number of procedures with only one offer was 91 (weight $68.93 \%$ ), the average number of offers received for every procedure was of 1.52 offers / procedure. Therefore, authors consider that car manufacturers have founded some divisions that participate in public procurement procedures and have forbidden to their dealers' to get involved in public procurement procedures. These dealers can sell cars only to individuals and other firms and only the company at national level is involved in the procurement procedures and hardly ever their dealers (Popescu and Preda, 2019).

\section{Conclusions}

The study found that the main advantages of the procurement procedures in which was received only one tender are reduction of workload necessary for the analysis of submitted offer, reduction of offer assessment period and reduction or elimination of the risk for 
appeals and the main disadvantages are reduction of competition which can lead to a weaker position of contracting authority and award of some offers with higher prices.

Also, the study showed that in Romania, in the period 2015 - 2017, the number and weight of contracts based on only one offer almost doubled in the year 2017 by comparison with the years 2015 and 2016.

The weight of the contracts awarded on the basis of a single tender in Romania is increasing, in 2017 finding that $43 \%$ of the contracts were awarded based on a single tender, one of the highest weights at European level, given that the weight of small and medium-sized companies that won contracts in Romania was the lowest in the European Union (17\%), although between 2015 and 2017 Romania had the highest weights in the EU of procurement procedures divided into lots (between $48 \%$ and $56 \%$ ).

Even if in 2016 ANAP took measures regarding the division into lots of the object of the procurement procedure, these did not have the expected result, because in 2017 Romania presented the lowest weight of all EU Member States of small and medium-sized companies that have won contracts and one of the highest weight at EU level of contracts awarded on the basis of a single tender. Therefore, in the case of Romania, the working hypothesis according to which the division into lots leads to the increase of the number of small and medium-sized companies participating in procedures (increased competition) and to the reduction of the number of procedures in which a single tender was received is rejected.

Because the reduction of competition has led to the increase of the final prices and implicitly to the inefficient spending of the public funds, further measures are needed that will lead to an increase of the weight of small and medium-sized companies that will win contracts in Romania.

Furthermore, the study revealed that receiving of only one tender can be an indicator (red flag) regarding to appearance of fraud or corruption situations, to existence of procurement procedures "with dedication", in which technical specifications have been designed to artificially restrict competition or to existence of anticompetitive agreements between various economic operators.

\section{References}

ANAP - Romanian National Agency for Public Procurement, 2015. Indicatorii de monitorizare a eficienței procedurilor de achiziție publică finalizate prin contract/acord-cadru în anul 2015, [online], Available at http://anap.gov.ro/web/wp-content/uploads/2016/11/Indicatorii-de-monitorizare-ai-eficientei -procedurilor-de-achizitie-publica-pentru-anul-2015.pdf, [Accessed 18 December 2017]. ANAP - Romanian National Agency for Public Procurement, 2016. Indicatorii de monitorizare a eficienței procedurilor de achiziție publică finalizate prin contract/acord-cadru în anul 2016, [online], Avaible at http://www.anap.gov.ro/Indicatorii-de-monitorizare-a-eficienței-procedurilor-de-achiziție-pub lică-finalizate-prin-contract/acord-cadru-în-anul-2016/, [Accessed 20 December 2017]. ANAP - Romanian National Agency for Public Procurement, 2017. Indicatorii de monitorizare a eficienței procedurilor de achiziție publică finalizate prin contract/acord-cadru în anul 2017, [online], Avaible at http://anap.gov.ro/web/wp-content/uploads/2018/06/Indicatorii-de-monitorizare-a-eficien\% C8\%9Bei-procedurilor-de-achizi\%C8\%9Bie-public\%C4\%83-finalizate-prin-contract-sau-ac ord-cadru-\%C3\%AEn-2017.pdf, [Accessed 2 December 2018].

European Commission, 2018. The EU Single Market - Single Market Scoreboard - Public Procurement, [online], Avaible at http://ec.europa.eu/internal_market/scoreboard/performance_per_policy_area/public_proc urement/index_en.htm, [Accessed 2 December 2018]. 
Gugler, K., Weichselbaumer, M. and Zulehner, C., 2014. Competition in economic crisis: Analisys of procurement auctions, p. 2, Elsevier.

Popescu, D. and Preda, I., 2019. Analysis of the Correlation between Competition and the Savings Obtained within the Automobile Public Procurement in Romania, $33^{\text {rd }}$ IBIMA Conference (International Business Information Management Association), 10 - 11 April, 2019, Granada, Spain.

Thai, K.V., Berman, E.M., and Rabin, J. (eds.) 2009. International Handbook of Public Procurement, Boca Raton: Taylor \& Francis Group.

Romanian Law no. 98/2016 regarding public procurement.

\section{Bio-note}

Ionel Preda is a PhD student in second year of study at the Doctoral School of Management, Bucharest University of Economic Studies and currently he is working on PhD thesis: "Contributions to improving public procurement management". 